\title{
What Do Riparian Landowners Know and Want? Survey Results from the Headwaters of the Potomac River
}

\author{
Maribel N. Mojica-Howell (Corresponding author) \\ Department of Agriculture, Alcorn State University \\ 1000 ASU Dr. \# 750Alcorn State, Mississippi 39096, U.S.A. \\ Tel: 1-601-877-2314Ｅ-mail: mmojica@alcorn.edu
}

Alan R. Collins

Division of Resource Management, West Virginia University

PO Box 6108Morgantown, West Virginia 26506, U.S.A.

Tel: 1-304-293-5486 E-mail: Alan.Collins@mail.wvu.edu

$\begin{array}{lcc}\text { Received: October 21, } 2011 & \text { Accepted: December 1, } 2011 \quad \text { Published: March 1, } 2012 \\ \text { doi:10.5539/enrr.v2n1p10 } & \text { URL: http://dx.doi.org/10.5539/enrr.v2n1p10 }\end{array}$

Funding for this research was provided by the Mid-Atlantic Regional Water Program through the Cooperative State Research, Education and Extension Service of the United States Department of Agriculture

\begin{abstract}
The purpose of this study was to examine riparian owner concerns, land uses, and interests in protecting river/stream quality. In collaboration with local watershed organizations, mail surveys were used to collect information from riparian landowners. Descriptive statistics and probit models were utilized to analyze survey data. Study findings revealed that trash is a consistent concern of riparian owners and that owner interest in watershed organization activities is high. Furthermore, results showed that there is generally a low interest in stream improvement projects among the surveyed individuals. Respondent characteristics that increased improvement interests included agricultural or idle land uses, higher education level, concern about stream pollution, and expressed interest watershed organization activities. Availability of government cost share was found to increase landowner interest in conducting more than one stream improvement project.
\end{abstract}

Keywords: Riparian owners, Stream improvement, Watershed organizations, Mail surveys

\section{Introduction}

Significant progress has been made in cleaning up polluted waters in the U.S., mainly through the abatement of industrial and municipal point sources (U.S. EPA, 2002; Ribaudo et al., 1999). However, nonpoint pollution, remains a continuing problem (Lombardo et al., 2000). The U.S. Environmental Protection Agency (2002) reported that $39 \%$ of the river and stream miles assessed were unable to support at least one of their designated uses. They estimated that nonpoint pollution, primarily from agriculture, impacts $48 \%$ of impaired rivers and $41 \%$ of impaired lakes. When the focus is on nonpoint pollution, riparian land management is important in its prevention, particularly the maintenance of forested land buffers (Barker, Felton \& Russek-Cohen, 2006; Lowrance et al., 1997).

Increasingly, nonpoint pollution problems are being addressed at a watershed level through management planning efforts such as computation of total daily maximum loads (TMDL). When TMDLs or water quality problems are managed at a watershed level, local stakeholder organizations, like collaborative watershed partnerships, have often arisen to address these problems (Lubell et al., 2002). In recent years, state governments have expanded their financial and technical support to these organizations (Hardy \& Koontz, 2008) and these organizations have been successful in addressing watershed problems and taking actions to improve water quality (Cline \& Collins, 2003). 
A number of riparian landowner surveyshave been reported in the literature. Ryan (2009) evaluated information sources and educational techniques for non-commercialriparian landowners in western Washington State. Dutcher et al. (2004) conducted interviews of forty riparian landowners in central Pennsylvania. They found that landowners were inconsistent in their concern versus their actual conservation behavior towards water pollution. An earlier survey of forest landownersin Oregon also found landowners to be inconsistent in their approach to riparian buffers - strong support for goals but much less implementation in practice (Hairston-Strang \& Adams, 1997).

Farmers have been a primary focus in a number ofriparian landowner surveys. Research has evaluated farmer decision making and willingness to participate in government stream conservation programs (Lynch et al., 2002; Lynch \& Brown, 2000; Kingsbury \& Boggess, 1999). Fielding et al. (2005) examined motivating factors for engaging in riparian zone management. Using a theory of planned behavior, they found that strong intentions to manage riparian areas were associated with behavior beliefs about favorable benefits versus costs of management and lower perceptions of barriers. Finally, Schrader (1995) found that agricultural landowners in Kansas were accepting of alternative management strategies (such as conservation easements and stream restoration) for riparian areas when they regarded these areas as important for community quality of life.

The motivationsfor watershed organizations to conduct surveys of riparian landowners are threefold: (1) their land uses have major impacts on water quality; (2) these organizations struggle to prioritize what problems to address with limited resources and figure out how to get citizens engaged in watershed protection; and (3) surveys of riparian owners can help provide local watershed groups with valuable local knowledge. Given these motivations, the research objectives of this study are to investigate the following questions:

- What are riparian owners concerned about in terms of environmental quality of the river/stream?

- What are they willing to do in terms of projects to improve the quality of the adjacent river/stream?

- How are their concerns, current land use, knowledge, and demographic characteristics related to their interest in projects to protect or improve stream quality?

Projects to improve stream quality encompass a range of potential landowner activities including aquatic habitat restoration, establishment of conservation buffers, fencing, providing more public access, streambank restoration, and tree planting. These improvement projects generate benefits to both the landowner and society in general (see Lovell \& Sullivan (2006) for a discussion of conservation buffers). In recognition of these public benefits, private landowners can receive cost share assistance for implementation of stream improvement projects from government programs, such as the Conservation Reserve Enhancement Program. In this study, riparian landowner interest in five improvement projects was examined: streambank restoration, tree planting, allowing public access, conservation easement, and fencing.

This study is focused on five different watersheds located in the eastern panhandle of West Virginia and northern Virginia (Figure 1). Each of these watersheds is a headwater tributary for the Potomac River and ultimately, the Chesapeake Bay. Within each watershed, water quality problems exist, primarily due to nonpoint pollution problems related to sedimentation and bacteria. Downstream, water quality in the Chesapeake Baysuffers from excess nutrients along with sediments.In its most recent assessment, the Chesapeake Bay Program (2011) found that water quality in the bay was at only $24 \%$ of its desired goal in 2009. According to Baker (2009), immense areas of the Chesapeake Bay and its tidal tributaries are essentially dead because of not enough dissolved oxygen to sustain healthy life.

In this research we find that riparian landowners were consistently concerned about trash, stream pollution and stream bank erosion. Their interest was high for activities of watershed organizations, but low for stream improvement projects. Our analyses of TMDL watersheds showed that agricultural landowners of riparian land were more interested in stream improvement projects than non-agricultural land owners. The existence of government cost share increased the frequency of multiple respondent responses to interest in stream improvement and increased interest in stream bank restoration and conservation easement improvement projects.

\subsection{Study areas}

Four of the surveyed watersheds are located in West Virginia: Cacapon River, Mill Creek, Sleepy Creek, and Tuscarora Creek. The Cacapon River is located in Hampshire and Morgan Counties while Sleepy Creek is located primarily in Morgan County. Both Mill and Tuscarora Creeks are located in Berkeley County and are tributaries of Opequon Creek as it flows through West Virginia. The fifth watershed, Opequon Creek, begins in Frederick County, Virginia and along with Abrams Creek covers both Frederick and Clarke Counties. 
Table 1 presents summary statistics for each of the five watersheds. Cacapon River is by far the largest watershed, while Opequon plus Abrams Creeks and Tuscarora watersheds are the most densely populated watersheds and contain the cities ofWinchester, VA and Martinsburg, WV, respectively. The dominant land uses are forest and agriculture in each watershed, with the exception of Tuscarora which is almost one-third urban. Cacapon River has a population density close to the West Virginia statewide average, while Mill and Sleepy Creeks have slightly higher population densities. Tuscarora Creek and Opequon plus Abrams Creek watersheds have population densities much higher than their statewide averages (29 and 77 per square kilometer for West Virginia and Virginia, respectively).

Water quality issues in each watershed are focused mainly on bacteria, sedimentation, and nutrients from agriculture and development. All of these watersheds are impacted by increasing population growth, which has influenced land use changes. All of the counties where the watersheds are located have experienced population growth rates higher than their respective states and the national average during the past decade. Three of the watersheds: Mill, Tuscarora and Opequon plus Abrams Creeks are located within areas where streams are listed on the state's 303(d) lists and TMDLs have been written (Tetra Tec, 2008; Virginia Department of Environmental Quality, 2004). Water quality problems include fecal coliform and benthic impairment (linked to excessive sediment and nutrients). All three watersheds are part of the greater Opequon Creek watershed, which has been identified as the first priority watershed West Virginia Potomac Tributary Strategy's Implementation Plan to reduce nutrients and sediment delivered to the Chesapeake Bay.

\section{Methods}

\subsection{Survey}

Five mail surveys were conducted between fall 2005 and summer 2009. Each survey was conducted as collaborative research effort between a local watershed organization and West Virginia University researchers. For each survey, respondent contact was limited to two survey mailings and a postcard due to budgetary constraints. While questions included in each survey differed slightly based on problems or issues within each watershed, common questions to each survey included how owners utilized riparian land, their concerns about the watershed, their interest in watershed group activities, and owner interest in conducting stream improvement projects. Demographic data were not collected in most of the surveys in order to minimize survey length.

Over the five surveys, a total of 976 riparian landowners were sent a mail survey (see Table 2). Mail surveys were sent out to complete riparian landowner populations for Mill, Sleepy, and Tuscarora Creeks. Due to their larger populations of landowners, random samples were selected in Cacapon River and Opequon plus Abrams Creek watersheds. About one-third of landowners along the Cacapon River were sent a survey and one-half of riparian landowners in Opequon and Abrams Creeks received a survey. Survey response rates were greater than $50 \%$ in Mill and Tuscarora Creeks which were small watersheds with severe enough water quality problems to warrant TMDL. Larger watersheds and those without a TMDL had response rates around one-third of the sample.

\subsection{Data analyses}

Data for riparian land use and respondent concerns about the stream located adjacent to their property were summarized by watershed. Percentages of respondents aware of watershed group and TMDL (where applicable) were computed. To show the public good nature of stream improvement projects, percentages of respondent interest in improvement projects on their property versus the river in general were computed for the Cacapon River.

In the three watersheds where a TMDL has been prepared (Mill Creek, Opequon plus Abrams Creeks, and Tuscarora Creek), respondent interest in stream improvement projects conducted on their own property were evaluated using three methods: (1) percentages of respondents interested in stream improvement projects were compared with versus without government cost share; (2) chi-square tables and tests of independence between project choices; and (3) limited dependent variable models explaining respondent interest. Six stream improvement project alternatives were presented in the surveys: stream bank restoration, tree planting, allowing public access, conservation easement, fencing, and none. Those respondents who indicated that they had already done these improvements were excluded from this analysis.

Riparian landowner interest in one stream improvement project was expected to be related with her or his interest in other projects (i.e. conservation easements and fencing). Data were combined over all three watersheds and two tests of independence were conducted: (1) improvement projects at riparian owners' own expense; and (2) improvement projects with government cost share. 
Since respondents were asked to express interest in stream improvement projects as a yes or no response, limited dependent variable models were utilized to explain the probability of a "yes" response. As a binary response, respondent interest in stream improvement projects was treated as a latent variable model. In this case, the latent variable $\left(y_{i}^{*}\right)$ represented the perceived net benefit by the respondent from the $i^{\text {th }}$ stream improvement project. The unobserved $y_{i}^{*}$ was assumed to be a linear function of independent variables $(X)$ such as respondent characteristics, perceived stream problems, availability of government cost share, and riparian land use plus an error term $(e)$ as independent from $X$.

If $y_{i}^{*}>0$, then a respondent will indicate an interest in the $i^{\text {th }}$ stream improvement project (recorded as $y_{i}=1$ ), otherwise $y_{i}=0$. Following Wooldridge (2006), the probability of observing $y_{i}=1$ can be expressed as:

$$
\mathrm{P}\left(y_{i}=1 \mid X\right)=\mathrm{P}\left(y_{i}^{*}>0 \mid X\right)=\mathrm{P}(\mathrm{e}>-X \beta \mid X)=\mathrm{G}(X \beta)
$$

Here, $\mathrm{G}($ ) was assumed to be a standard normal cumulative distribution function so that a probit model wasutilized. This model remains strictly between zero and one with a normality assumption for error term (Wooldridge, 2006).

Two separate sets of probitmodels were estimated: (1) Data from Mill and Tuscarora Creeks where complete riparian land use data were available but no respondent demographic data were collected; and (2) Opequon plus Abrams Creeks where limited riparian landowner land use data were collected but respondent demographic data were available. Dependent variables measured a respondent's expressed interest in the six stream improvement project alternatives presented in the survey. Explanatory variables included respondent characteristics such as riparian land use, respondent concerns about the stream, respondent knowledge of TMDL, watershed group awareness, agricultural land owner, government cost share, and respondent demographics.

Positive impacts on the probability of a "yes" response included those variables suspected of increasing the perceived net benefit of a stream improvement project, such as government cost share, idle riparian land, the project addresses a riparian landowner stream concern, and knowledge about the stream's TMDL. Negative impacts were anticipated from variables which may lower the perceived net benefits such as agricultural land use or a project that does not address a riparian landowner stream concern. A complete list of variables utilized in these analyses is found in Table 3.

Marginal effect coefficients for the expected value of the dependent variable were evaluated for each independent variable at the means of the other variables. For zero/one variables, marginal effect coefficients were computed by the probability evaluated on one minus the probability evaluated at zero. Probability values for coefficients different from zero were computed to evaluate statistical importance of each explanatory variable. Chi-square tables, tests of independence, and limited dependent variable probit models were analyzed with LIMDEP Version 7.0 (Greene, 2007).

\section{Results}

Among the five watersheds, the dominant land uses of riparian land were residential and agricultural, although more than one land use was commonly reported by respondents. Residence percentages ranged from a low of 50\% (Sleepy Creek) to a high of $84 \%$ (Tuscarora Creek). Agricultural land use percentages ranged froma low of $6 \%$ on the Cacapon River to $42 \%$ on Mill Creek. Sizable portions of riparian land were reported to be currently idle along Sleepy Creek (36\%), Mill Creek (19\%), and Cacapon River (18\%).

Riparian landowners were asked to identify their concerns about the creek or river where their land was located. The top three concerns were fairly consistent across all watersheds: stream pollution (average of $70 \%$ ), trash in the stream (average of $67 \%$ ), and streambank erosion (average of $49 \%$ ). Other concerns identified less frequently by respondents included: flooding (between 20 and 40\%), wildlife (between 10 and $40 \%$ ), stream course changes (around 20\%), and recreational users (between 10 and 20\%).

In all five watersheds, a local watershed group or partnership existed prior to the survey. When asked in three different surveys, riparian landowner awareness of these local watershed organizations varied considerably. In Mill and Tuscarora Creeks, awareness of the Opequon Creek Project Team was low at $17 \%$ and $31 \%$ of respondents, respectively. In Sleepy Creek, however, $83 \%$ of respondents were aware of the Sleepy Creek Watershed Association.

The surveys did prove to be a successful instrument in engaging the interest of riparian landowners in the activities of their local watershed group. In four of the surveys, respondents were asked if they would like more information about the local watershed group.The percentage of respondents who were interested in more 
information or identified themselves as group members already was high in each watershed - Cacapon River (68\%), Mill Creek (56\%), Sleepy Creek (69\%), and Tuscarora Creek (71\%).

In the three watersheds where a TMDL has been prepared, riparian landowner knowledge about TMDLs tended to be low. Thirty percent of respondents were aware prior to the survey in Opequon plus Abrams Creeks about an already completed TMDL. Surveys were conducted in West Virginia while TMDLs were in development. Only 3\% and 14\% of respondents were aware of the TMDLs in Mill and Tuscarora Creeks, respectively.

In these TMDL watersheds, riparian landowners were asked separate questions about whether they would consider doing stream improvement projects at own expense and with government cost share.Overall, landowner interest in stream improvements was not very high at their own expense as almost half responded with "none" (Figure 2). Tree planting was the most accepted improvement with over one-fourth of respondents (28\%) expressing an interest. As Figure 2 shows, over all three watersheds, acceptance of stream improvement projects increases with the availability of government cost share, particularly the potential most expense improvement stream bank restoration. The choice of none dropped dramatically with government cost share from almost $50 \%$ to under one-third.

There were three combinations of stream improvement projects that tended to be selected together: (a) conservation easement and fencing; (b) conservation easement and tree planting; and (c) streambank restoration and tree planting (Table 4). Chi-squared tests for independence rejected the null hypothesis of independence for these combinations both with and without government cost share. With government cost share available, respondents were more likely to express interest in multiple projects, particularly tree planting, public access, and conservation easements. In each case of a statistically significant chi-square reported in Table 4, there was a positive association between expressed interests in one stream improvement project versus the other one.

Probit model resultsfor interest in stream improvement projects are summarized in Table 5 for Mill and Tuscarora Creek watersheds and in Table 6 for Opequon plus Abrams Creek watershed. Probit model estimation results were not included for the variable public access due to low statistical confidence levels in the marginal effect coefficients and the models themselves, most likely because so few respondents expressed interest in public access. Both tables show only those marginal effect coefficients with a probability value of $p \leq 0.10$ and a summary of model statistics. With the exception of the stream bank restoration model in Opequon plus Abrams Creek watershed, all modelshad statistical confidence levels of $p \leq 0.01$.

Riparian land use was an indicator of interest in stream improvement project for three of the five models reported in Mill and Tuscarora watersheds (Table 5). As expected, those landowners who held their riparian land idle were more interested instream improvement projects for fencing, tree planting, and any project in general. Surprisingly, agricultural riparian landowners were more interested in fencing than non-agricultural landowners. In addition, agricultural landowners in Opequon plus Abrams Creek watershed were found to be more likely interested in all stream improvement projects except streambank restorationthan other landowners (Table 6). The agricultural land owner variable had the largest marginal effect coefficient in three models - conservation easement, fencing, and tree planting.Thus, agricultural landowners were more likely, to express an interest in stream improvement projects than other landowners.

Based on the number of marginal effect coefficients with statistical confidence levels of $p \leq 0.10$, respondent concerns about streams were more important in Mill and Tuscarora than in Opequon plus Abrams watersheds. In Mill and Tuscarora, bank erosion and pollution concerns had positive impacts on more than one type of project with both concerns leading to a more likelynegative response to "none" (Table 5). Concern about trash was found to increase interest in conservation easements but decreased interest in streambank restoration. Similarly, flooding concerns decreased respondent interest in conservation easements.

Only bank erosion concerns were statistically important for stream improvement projects in Opequon plus Abrams (Table 6). Much like trash concerns, its influence was negative for conservation easement, which does not address this concern. Thus, in all three watersheds, when a respondent has concerns that are not addressed by a stream improvement project, this concern could lead to a reduced interest in that project.

Among respondent knowledge and demographic variables, riparian landowner interest in watershed groups extended to stream improvement projects as respondents who requested information about a watershed group were more likely to express interest in every improvement project except fencing (Table 5). TMDL knowledge had strong, positive impactson stream bank improvement and tree planting interest with the largest marginal effect coefficientsfor the Mill and Tuscarora model. Interestingly, this same knowledge had a negative impact in Opequon plus Abrams Creeks of Virginia for tree planting and for any project.Requesting information about the 
watershed organization was important in explaining stream improvement interest in Mill and Tuscarora for every model but fencing.

Based on Opequon plus Abrams Creek results, respondent demographics, particularly education level, were important in explaining interest in stream improvement projects. The positive influences of education and gender along with the negative impact of age on interest in stream improvement projects corresponds to research findings of younger, female, and higher education respondents having greater environmental concerns (Inglehart, 1990; Sahmdahl \& Robertson, 1989; Buttel, 1979).

As expected, government cost share was found to increase interest in stream improvement projects in all three watersheds (Tables 5 and 6). However, marginal effect coefficients with statistical confidence levels of $p \leq 0.10$ existed for only streambank restoration and conservation easement improvements. In most models, the government cost share marginal effect coefficient was smaller than other variable impacts, such as agricultural land ownership, TMDL knowledge, or respondent stream concerns. Respondent interest in less expensive improvement projects, such as fencing and tree planting, were not impacted by the availability of government cost share.

Finally, due to free ridership, rational individuals tend to desire that public goods be provided by others (particularly the government) and not themselves (Callen \& Thomas, 2000). This public good aspect of stream improvement projects was revealed quite dramatically by respondents in the Cacapon River watershed. Riparian landowners were asked to state their interest in stream improvement projects on their own property along with what they believed should be done on the river in general. Overall, Cacapon River respondents were similar to respondents in other watersheds in regards to the percentages interested in projects such as tree planting and conservation easements being conducted on their own property (see Table 7 and Figure 2). However, respondents were found to two to four times more likely to believe that stream improvement projects should be done on the river in general than being interested in doing such projects on their own property (Table 7). With the exception of the "none" response, all the differences in percentages between own and the river in general were significant at $p \leq 0.01$. In the case of public access, there was zero interest from respondents on their own property versus $15 \%$ indicating that it should be done on the river in general.

\section{Summary and Conclusions}

Mail surveys of riparian landowners were conducted on five watersheds in the Potomac River basin. These surveys proved to be a productive means for local watershed organizations to contact this important group of watershed residents. These surveys provided useful information about landowner perceptions and expanded contact lists of landowners interested in their local watershed organization. Survey questions included:landowner concerns about the watershed, their interest in watershed group activities, how riparian land was utilized, and owner interest in conducting stream improvement projects (stream bank restoration, tree planting, allowing public access, conservation easement, and fencing).

A consistent concern of riparian owners was trash in the stream. Even though trash is not a TMDL or regulatory issue, trash clean-ups are often done by watershed groups in order to take action to address this common concern. While trash is a watershed level concernand not a Potomac River or Chesapeake Bay concern, multiplewater quality concerns need to be made compatible in order to achieve water quality improvements. This is particularly important because probit model results from the Mill and Tuscarora Creek watersheds show evidence that trash concerns actually lowers interest in stream improvement projects. Thus, when watershed organizations address trash concerns of their community, these efforts need to be coordinated with educational efforts about other stream problems.

Interest among riparian landowners in watershed organization activity was highacross all surveys (50 to $70 \%$ of respondents), while awareness of TMDL regulatory plans was low (30\% or lower) in the three watersheds where these plans were prepared. A respondent's interest in his local watershed organization interest was found to have positive influences within four of the five probit models on stream improvement projects in Mill and Tuscarora Creek watersheds. However, knowledge of TMDL was found to not always have a positive impact on interest in stream improvement projects. The influence of TMDL knowledge may be related to the stage of TMDL development. The negative influences in Opequon plus Abrams Creek watershed may be reflective of a completed TMDL where respondents who are familiar with the TMDL could identify human activities other than their own for corrective action to prevent pollution. The positive impacts in Mill and Tuscarora Creek models were based on surveys conducted prior to TMDL completion.

Overall, interest in stream improvement projects among riparian landowners tended to be low. The highest level of interest expressed was in stream bank restoration with government cost share with $40 \%$ of respondents 
expressing an interest. The projects presented to respondents in these surveys have a strong public good component as evidenced by Table 7 results from the Cacapon River watershed where much higher percentages of respondents felt stream improvements should be done on the river in general rather than their own property. Government cost share was found to have a moderate sized, positive impact on riparian landowner interest in multiple improvement projects. Cost sharing had its most important impact on projects which are more expensive (stream bank restoration) or have long term land use implications (conservation easements) for the owner.

Probit model results revealed a couple of interesting findings: (1) that riparian agricultural land owners were not less interested in stream improvement projects than non-agricultural land owners; and (2) it is important to include questions about respondent demographics in surveys for research purposes. For the first finding, the marginal effect coefficients for agricultural land ownership were positive and large in all three watersheds in explaining interest in stream improvement. This finding is contrary to our initial expectation of a negative impact from agricultural land ownership. Obviously, owning agriculture land, even in riparian areas, does not connote a perception of lower net benefits from stream improvement projectscompared to non-agricultural land owners.

The second finding is that respondent demographics dominated stream concern variables when explaining interest in stream improvements. Without respondent demographics in Mill and Tuscarora Creeks, there were eight stream concern variables with marginal effect coefficients that had statistical confidence levels of $p \leq 0.10$. Conversely, only one stream concern variable in the Opequon plus Abrams Creek watershed models versus seven respondent demographic variables had marginal effect coefficients with statistical confidence levels of $p \leq$ 0.10 .

One limitation of this research was that interest in stream improvement project was asked as a stated intention and not actual behavior. While actual behavior is preferable and the surveys wereanonymous, many respondents who stated interest in projects also provided their contact information as a request for more information about the watershed organization. Thus, there is an opportunity for these intentions to be pursued to actions through watershed organizations. Another limitation was that government cost share was not described in much detail in the survey questions. It is possible that more detail may have attracted more interest in stream improvement projects.

Finally, without respondent demographic variables in the Mill and Tuscarora Creek model or riparian land use in the Opequon plus Abrams Creek model, probit model misspecification represents a problem. With a nonlinear probit model, omitted variables may produce biased coefficientseven if they are uncorrelated with included variables and this bias increases as their distribution deviates from normal (Yatchew \& Griliches, 1985).However, determination of the precise effect of omitted variableson model coefficients is difficult and examining the effect of including a subset of relevant omitted variables is nearly impossible. In practice, omitted variable bias is unavoidable since it is almost impossible to include all relevant variables in a regression model and the inclusion of a subset of relevant control variables may even increase biases through measurement errors (Clarke, 2005).

The bottom line is that omitted variables may pose problemsfor interpretation of the marginal effect coefficients in our probit models. Despite these problems, our results show that respondent demographics and riparian land use are important variables to include when explaining interest in stream improvement projects while respondent stream concerns seem to have less relevance when demographics are available.

\section{References}

Baker, W. (2009). Chesapeake Bay restoration: Status report and recommendations. Statement made to U.S. Senate Committee on Environment and Public Works Subcommittee on Water and Wildlife. [Online] Available: http://epw.senate.gov/public/index.cfm?FuseAction=Files.View\&FileStore_id=83140885-5d74-4a0d-a270-63bc b58163e9(April 20, 2009).

Barker, L. S., Felton, G.K., \& Russek-Cohen, E. (2006). Use of Maryland biological stream survey data to determine effects of agricultural riparian buffers on measures of biological stream health. Env. Monitoring and Assessment, 117, 1-17. http://dx.doi.org/10.1007/s10661-006-7721-3

Benson, M. C. (2006). An Economic Valuation of Improved Water Quality in Opequon Watershed. Unpublished M.S. Thesis, West Virginia University, Morgantown, WV.

Buttel, F. H. (1979). Age of environmental concern: A multivariate analysis. Youth and Society, 10, 237-56.

Callen, S. J., \& Thomas, J. M. (2000). Environmental Economics and Management Theory, Policy, and Applications $\left(2^{\text {nd }}\right.$ ed.). Dryden Press: Fort Worth. 
Chesapeake Bay Program. (2011). Baywater quality. [Online] Available: http://www.chesapeakebay.net/status_waterquality.aspx?menuitem=19646

Clarke, K. A. (2005). The Phantom Menace: Omitted Variable Bias in Econometric Research. Conflict Manage. and Peace Science, 22(4), 341-352. http://dx.doi.org/10.1080/07388940500339183

Cline, S., \& Collins, A. R. (2003). Watershed associations in West Virginia: Their impact on environmental protection. J. Env. Manage., 67(4), 373-383. http://dx.doi.org/10.1016/S0301-4797(02)00222-0

Constantz, G., Ailes, N., \& Malakoff, D. (2005). Portrait of a river: The ecological baseline of the CacaponRiver. Cacapon Institute, High View, [Online] Available: http://www.cacaponinstitute.org/PDF/Portrait\%20of\%20a\%20River.pdf

Dutcher, D. D., Finley, J. C., Luloff, A. E., \& Johnson, J. (2004). Landowner perceptions of protecting and establishing riparian forests: A qualitative analysis. Society Nat. Resources, 17, 329-342. http://dx.doi.org/10.1080/08941920490278773

Fielding, K. S., Terry, D. J., Masser, B. M., Bordia, P., \& Hogg, M. A. (2005). Explaining landholders' decisions about riparian zone management: The role of behavioral, normative, and control beliefs. J. Env. Manage., 77, 12-21. http://dx.doi.org/10.1016/j.jenvman.2005.03.002

Greene, W. H. (2007). LIMDEP Version 7.0.Econometric Software: Plainview, NY.

Hairston-Strang, A. B., \& Adams, P. W. (1997). Oregon's streamside rules: Achieving public goals on private land. J. For., 95(7), 14-18.

Hardy, S. D. \& Koontz, T. M. (2008).Reducing nonpoint source pollution through collaboration: Policies and program across the U.S. States. Env. Manage., 41, 301-310. http://dx.doi.org/10.1007/s00267-007-9038-6

Hartman, A., Bennett, J., Gaujot, R., Mielcarek, K., \& Winant, E. (2008). Watershed based plan for Mill Creek Berkeley County, WV. Prepared for the West Virginia Department of Environmental Protection. [Online] Available:

http://www.epa.gov/reg3wapd/nps/pdf/watershed_plans/wv/Watershed\%20Based\%20Plan\%20for\%20Mill\%20 CreekMAY_1_08.pdf

Hartman, A., \& Mielcarek, K. (2010). Draft copy of Tuscarora Creek watershed based plan Berkeley County, $W V$. Prepared by the West Virginia Department of Environmental Protection, Romney, WV.

Inglehart, R. (1990). Culture Shift in Advanced Industrial Society. Princeton University Press: Princeton, N.J.

Kingsbury, L., \& Boggess, W. (1999). An economic analysis of riparian landowners' willingness to participate in Oregon's Conservation Reserve Enhancement Program.Presented paper at the American Agricultural Economics Association Annual Meeting, Nashville, TN.

Lombardo, L. A., Grabow, J., Spooner, D. E., Line, D. E., Osmond, D. L., \& Jennings, G.D. (2000). Section 319 Nonpoint Source National Monitoring Program Successes and Recommendations. Raleigh, North Carolina: Water Quality Group, Biological and Agricultural Engineering Department, NC State University.

Lovell, S. T., \& Sullivan, W. C. (2006). Environmental benefits of conservation buffers in the United States: Evidence, promise, and open questions. Agriculture, Ecosystems and Environment, 112, 249-260. http://dx.doi.org/10.1016/j.agee.2005.08.002

Lowrance, R., Altier, L. S., Newbold, J. D., Schnabel, R. R., Groffman, P. M., Denver, J. M., Corell, D. L., Gilliam, J. W., Robinson, J. L., Brinsfield, R. B., Lucas, W., \& Todd, A. H. (1997). Waterquality functions of riparian forest buffers in Chesapeake Bay watersheds. Env. Management. 21(5), 687-712. http://dx.doi.org/10.1007/s002679900060

Lubell, M., Schneider, M., Scholz, J., \& Mete, M. (2002). Watershed partnerships and the emergence of collective action institutions. American J. of Political Science, 46, 148-163. http://dx.doi.org/10.2307/3088419

Lynch, L., \& Brown, C. (2000). Landowner decision making about riparian buffers. J. Agri. and Applied Econ, 32(3), 585-596.

Lynch, L., Hardie, I., \& Parker, D. (2002). Analyzing agricultural landowners' willingness to install streamside buffers.Working paper 28570, Department of Agricultural and Resource Economics, University of Maryland, College Park, MD.

Ribaudo, M.O., Horan, R. D., \& Smith, M. E. (1999). Economics of water quality protection from nonpoint sources: Theory and practice. USDA, Economic Research Service Agricultural Economic Report \#782. [Online] 
Available: http://www.ers.usda.gov/publications/aer782/aer782.pdf.http://dx.doi.org/10.2307/1349883

Ryan, C. M. (2009). Managing nonpoint source pollution in western Washington: Landowner learning methods and motivations. Env.Manage., 43, 1122-1130. http://dx.doi.org/10.1007/s00267-008-9240-1

Sahmdahl, D. M., \& Robertson, R. (1989). Social determinants of environmental concern. Environment and Behavior, 21, 57-81.

Schrader, C. C. (1995). Rural greenway planning: the role of stream land perception in landowner acceptance of land management strategies. Landscape and Urban Planning, 33, 375-390. http://dx.doi.org/10.1016/0169-2046(94)02029-F

Sleepy Creek Watershed Association. (2006). Sleepy Creek Watershed Assessment Morgan County, WV. [Online]

Available:

http://www.sleepycreekwatershedassociation.org/Content/2005StreamSurvey/Sleepy\%20Creek\%20Watershed\% 20Assessment.pdf

Snyder, C.D., Young, J. A., Villella, R., \& Lemarie, D. P. (2003). Influences of upland andriparian land use patterns on stream biotic integrity. Landscape Ecology, 18, 647-664. http://dx.doi.org/10.1023/B:LAND.0000004178.41511.da

Tetra Tec. (2008). Total daily maximum loads for selected streams in the Potomac direct drains watershed, West Virginia. Report prepared for the West Virginia Department of Environmental Protection. [Online] Available: http://www.dep.wv.gov/WWE/watershed/TMDL/grpc/Pages/default.aspx.

U.S. Environmental Protection Agency. (2002). Waterquality conditions in the United StatesA Profile from the 2000 National Water Quality Inventory. [Online] Available: http://www.epa.gov/305b/2000report/factsheet.pdf.

Virginia Department of Environmental Quality. (2004). Bacteria TMDLs for Abrams Creek and Upper and Lower Opequon Creek Located in Frederick and Clarke County Virginia. [Online] Available: http://www.deq.virginia.gov/tmdl/apptmdls/shenrvr/abropefc.pdf

Wooldridge, J. M. (2006). Introductory Econometrics A Modern Approach $\left(3^{\text {rd }} \mathrm{ed}\right)$. Thomson Southwestern: Mason, $\mathrm{OH}$.

Yatchew, A., \& Griliches, Z. (1985). Specification error in probit models. The Review of Economics and Statistics, 67(1), 134-139. http://dx.doi.org/10.2307/1928444 
Table 1. Summary descriptions of study area watersheds

\begin{tabular}{|c|c|c|c|c|c|}
\hline Watershed & $\begin{array}{l}\text { Size } \\
\left(\mathrm{km}^{2}\right)\end{array}$ & $\begin{array}{l}\text { Main Stem } \\
\text { Length }(\mathrm{km})\end{array}$ & $\begin{array}{c}\text { Estimated } \\
\text { Population } \\
\text { Densityper } \mathrm{km}^{2 \mathrm{a}}\end{array}$ & $\begin{array}{l}\text { Major land } \\
\text { uses b }(\%)\end{array}$ & Water Quality Issues \\
\hline \multicolumn{6}{|l|}{ West Virginia } \\
\hline Cacapon River & 767 & 180 & 30 & $\begin{array}{l}\text { Forest (79)Ag } \\
\text { (19)Urban (2) }\end{array}$ & $\begin{array}{c}\text { Sedimentation and stream } \\
\text { side development }\end{array}$ \\
\hline Mill Creek & 77 & 23 & 50 & $\begin{array}{l}\text { Forest (41)Ag } \\
\text { (34)Urban (14) }\end{array}$ & $\begin{array}{l}\text { Organic enrichment, } \\
\text { sedimentation, and } \\
\text { bacteria }\end{array}$ \\
\hline Sleepy Creek & 376 & 68 & 40 & $\begin{array}{l}\text { Forest (56)Ag } \\
(18) \text { Urban (12) }\end{array}$ & $\begin{array}{l}\text { Sedimentation and } \\
\text { population growth }\end{array}$ \\
\hline $\begin{array}{l}\text { Tuscarora } \\
\text { Creek }\end{array}$ & 67 & 19 & 124 & $\begin{array}{l}\text { Urban (32)Ag } \\
\text { (27)Forest (23) }\end{array}$ & $\begin{array}{l}\text { bacteria and benthic } \\
\text { impairment }\end{array}$ \\
\hline \multicolumn{6}{|l|}{ Virginia } \\
\hline $\begin{array}{c}\text { Opequonplus } \\
\text { Abrams Creeks }\end{array}$ & 393 & 71 & 190 & $\begin{array}{l}\text { Ag (53)Forest } \\
\text { (33)Urban (14) }\end{array}$ & $\begin{array}{l}\text { bacteria and benthic } \\
\text { impairment }\end{array}$ \\
\hline
\end{tabular}

${ }^{a}$ Watershed populations were estimated based on: 2009 Census data for Hampshire County for Cacapon River; WVDEP 2008 for Mill Creek; 2009 Census data for Morgan County for Cacapon River; 2009 Census data for Berkley County for Tuscarora Creek; and Benson (2006) for Opequon plus Abrams Creeks

bources: Constantzet al. (2005), Hartman et al. (2008), Sleepy Creek Watershed Association (2006), Benson (2006), Hartman and Mielcarek (2010)

Table 2. Survey sample sizes and response rates

\begin{tabular}{|c|c|c|c|c|}
\hline Watershed & Sample Size $^{\mathrm{a}}$ & $\begin{array}{c}\text { Number of Returned } \\
\text { Surveys }\end{array}$ & $\begin{array}{c}\text { Response Rate } \\
(\%)\end{array}$ & $\begin{array}{c}\text { Riparian Owners } \\
(\%)\end{array}$ \\
\hline West Virginia & & & & \\
\hline Cacapon River & 312 & 94 & 30.1 & 93.6 \\
\hline Mill Creek & 78 & 40 & 51.3 & 77.5 \\
\hline Sleepy Creek & 354 & 101 & 28.5 & 94.1 \\
\hline Tuscarora Creek & 55 & 28 & 50.9 & 85.7 \\
\hline Virginia & & & & \\
\hline Opequonplus AbramsCreeks & 177 & 61 & 34.5 & 80.0 \\
\hline TOTALS & 976 & 324 & 33.2 & 88.5 \\
\hline
\end{tabular}

${ }^{\mathrm{a}}$ Computed by the number of surveys sent out minus returned undeliverables. 
Table 3. Variables utilized in probit models

\begin{tabular}{|c|c|c|c|}
\hline \multirow[t]{2}{*}{ Variable } & \multirow[t]{2}{*}{ Description } & \multicolumn{2}{|c|}{ Descriptive Statistics } \\
\hline & & $\begin{array}{l}\text { Mill/Tuscarora } \\
\text { MeanN=103 }\end{array}$ & $\begin{array}{l}\text { Opequon } \\
\text { plus Abrams } \\
\text { MeanN=82 }\end{array}$ \\
\hline \multicolumn{4}{|c|}{ Dependent Variables } \\
\hline $\begin{array}{l}\text { Conservation Easement } \\
\text { Fencing } \\
\text { Public Access } \\
\text { Streambank Protection } \\
\text { Tree Planting } \\
\end{array}$ & $\begin{array}{c}1=\text { Respondent expressed an interest in considering } \\
\text { an improvement on own land, } 0=\text { no interest } \\
\text { expressed }\end{array}$ & $\begin{array}{l}0.14 \\
0.15 \\
0.06 \\
0.34 \\
0.32\end{array}$ & $\begin{array}{l}0.26 \\
0.18 \\
0.05 \\
0.24 \\
0.31\end{array}$ \\
\hline None & $\begin{array}{c}1=\text { Respondent did not check none when asked to } \\
\text { express an interest in stream improvement projects, } \\
0=\text { Respondent checked none }\end{array}$ & 0.61 & 0.60 \\
\hline \multicolumn{4}{|c|}{ Riparian Land Use } \\
\hline Agriculture & $\begin{array}{c}1=\text { riparian land used for agriculture, } 0=\text { no } \\
\text { agriculture }\end{array}$ & 0.33 & n.a. \\
\hline Idle & $\begin{array}{l}1=\text { riparian land reported to be idle by the } \\
\text { respondent, } 0=\text { not idle }\end{array}$ & 0.17 & n.a. \\
\hline Recreation/ Wildlife & $\begin{array}{l}1=\text { riparian land used for recreation and/or } \\
\text { wildlife, } 0=\text { not used for these purposes }\end{array}$ & 0.22 & n.a. \\
\hline Residence & $\begin{array}{c}1=\text { riparian land used residence, } 0=\text { not used for } \\
\text { this purpose }\end{array}$ & 0.76 & n.a. \\
\hline \multicolumn{4}{|c|}{$\begin{array}{ll}\text { Stream Concerns } \\
\end{array}$} \\
\hline Bank Erosion & $\begin{array}{c}1=\text { Respondent indicated bank erosion among } \\
\text { stream concerns, } 0=\text { did not indicate bank erosion }\end{array}$ & 0.56 & 0.46 \\
\hline Flooding & $\begin{array}{l}1=\text { Respondent indicated flooding among stream } \\
\text { concerns, } 0=\text { did not indicate flooding }\end{array}$ & 0.34 & 0.38 \\
\hline Stream pollution & $\begin{array}{c}1=\text { Respondent indicated stream pollution among } \\
\text { stream concerns, } 0=\text { did not indicate stream } \\
\text { pollution }\end{array}$ & 0.63 & 0.83 \\
\hline Trash & $\begin{array}{c}1=\text { Respondent indicated trash among stream } \\
\text { concerns, } 0=\text { did not indicate trash }\end{array}$ & 0.67 & 0.68 \\
\hline \multicolumn{4}{|c|}{ Respondent Knowledge } \\
\hline Group & $\begin{array}{c}1=\text { Respondent reported being aware of the local } \\
\text { watershed group prior to receiving the survey, } \\
0=\text { not aware }\end{array}$ & 0.17 & n.a. \\
\hline Request & $\begin{array}{c}1=\text { Respondent requested more information about } \\
\text { the watershed organization in the survey, } 0=\text { did not } \\
\text { request more information }\end{array}$ & 0.70 & n.a. \\
\hline TMDL & $\begin{array}{l}1=\text { Respondent reported being aware of the TMDL } \\
\text { plan prior to receiving the survey, } 0=\text { not aware }\end{array}$ & 0.06 & 0.35 \\
\hline \multicolumn{4}{|c|}{ Respondent Demographics } \\
\hline Age & Age of respondent (years) & n.a. & 53 \\
\hline Education & $\begin{array}{c}\text { Education level of respondent } 1=\text { less than high } \\
\text { school, } 2=\mathrm{H} \text {.S. diploma or GED, } 3=\text { some college } \\
\text { or technical school, } 4=\text { college degree, } 5=\text { graduate } \\
\text { school }\end{array}$ & n.a. & 3.52 \\
\hline Gender & $1=$ Female, $0=$ male & n.a. & 0.45 \\
\hline \multicolumn{4}{|c|}{$\begin{array}{r}\text { Other Variables } \\
\end{array}$} \\
\hline Agriculture & $\begin{array}{c}1=\text { Respondent owned agricultural land, } \\
0=\text { otherwise }\end{array}$ & n.a. & 0.22 \\
\hline $\begin{array}{l}\text { Government Cost } \\
\text { Share }\end{array}$ & $\begin{array}{l}1=\text { Government cost share included in the interest } \\
\text { question, } 0=\text { improvement at the owner's expense }\end{array}$ & 0.46 & 0.51 \\
\hline
\end{tabular}


Table 4. Chi-squared test results for independence among stream improvement projects in the Mill, Tuscarora, and Opequon, plus Abrams Creeks watersheds, government cost share responses in upper portion and no government cost share in lower portion, $\chi^{2}$ with one degree of freedom

\begin{tabular}{|c|c|c|c|c|c|}
\hline & $\begin{array}{c}\text { Conservation } \\
\text { Easement }\end{array}$ & Fencing & Public Access & $\begin{array}{c}\text { Stream bank } \\
\text { Restoration }\end{array}$ & Tree Planting \\
\hline Conservation Easement & & $9.85^{\mathrm{a}}$ & $4.76^{\mathrm{b}}$ & 1.60 & $7.79^{\mathrm{a}}$ \\
\hline Fencing & $17.01^{\mathrm{a}}$ & & 2.34 & 2.09 & $3.44^{\mathrm{c}}$ \\
\hline Public Access & 0.39 & 0.39 & & $2.92^{\mathrm{c}}$ & $5.15^{\mathrm{b}}$ \\
\hline Stream bank Restoration & 1.13 & 1.13 & 0.12 & & $15.35^{\mathrm{a}}$ \\
\hline Tree Planting & $7.17^{\mathrm{a}}$ & 0.55 & 0.01 & $8.66^{\mathrm{a}}$ & \\
\hline
\end{tabular}

${ }^{\mathrm{a}}$ Statistically significant at the 0.01 level. ${ }^{\mathrm{b}}$ Statistically significant at the 0.05 level. ${ }^{\mathrm{c}}$ Statistically significant at the 0.10 level.

Table 5. Probit model results from Mill and Tuscarora Creek watersheds, only marginal effect coefficients with statistical confidence levels of $p \leq 0.10$ are reported in parentheses

\begin{tabular}{|c|c|c|c|c|c|}
\hline & \multicolumn{5}{|c|}{ Interest in Stream Improvement Project } \\
\hline $\begin{array}{c}\text { Variable } \\
\text { Categories }\end{array}$ & $\begin{array}{l}\text { Conservatio } \\
\text { n Easement }\end{array}$ & Fencing & $\begin{array}{l}\text { Stream bank } \\
\text { Restoration }\end{array}$ & Tree Planting & None \\
\hline $\begin{array}{l}\text { Riparian Land } \\
\text { Use Variables }\end{array}$ & & $\begin{array}{l}\text { Agriculture }(0.213)^{*} \\
\text { Idle }(0.480)^{* * *}\end{array}$ & & $\operatorname{Idle}(0.347)^{* *}$ & $\begin{array}{c}\text { Idle }(0.315)^{* * *} \\
\text { Recreation/Wil } \\
\text { dlife }(0.229)^{*} \\
\end{array}$ \\
\hline $\begin{array}{l}\text { Stream Concern } \\
\text { Variables }\end{array}$ & $\begin{array}{c}\text { Flooding } \\
(-0.106)^{* *} \\
\text { Trash } \\
(0.109)^{* *}\end{array}$ & & $\begin{array}{c}\text { Bank erosion } \\
(0.194)^{* *} \\
\text { Pollution }(0.171)^{*} \\
\text { Trash }(-0.287)^{* *}\end{array}$ & $\begin{array}{l}\text { Pollution } \\
(0.287)^{* * *}\end{array}$ & $\begin{array}{c}\text { Bank erosion } \\
(0.238)^{*} \\
\text { Pollution } \\
(0.263)^{*}\end{array}$ \\
\hline $\begin{array}{c}\text { Respondent } \\
\text { Knowledge } \\
\text { Variables }\end{array}$ & $\begin{array}{l}\text { Request } \\
(0.110)^{* *}\end{array}$ & & $\begin{array}{c}\text { Group(-0.149)* } \\
\text { Request }(0.413)^{* * *} \\
\text { TMDL }(0.587)^{*}\end{array}$ & $\begin{array}{c}\text { Request( }(0.313)^{*} \\
* * \operatorname{TMDL}(0.703) \\
* * *\end{array}$ & $\begin{array}{c}\text { Request }(0.448) \\
* * * \text { TMDL }(0.38 \\
2)^{* * *}\end{array}$ \\
\hline $\begin{array}{l}\text { Government Cost } \\
\text { Share Variable }\end{array}$ & $(0.082)^{*}$ & & $(0.265)^{* * *}$ & & $(0.321)^{* * *}$ \\
\hline Model Summary & & & & & \\
\hline $\begin{array}{l}\text { Number of obs. } \\
\text { Chi-squared } \\
\text { McFadden } R^{2}\end{array}$ & $\begin{array}{c}103 \\
24.96 * * *\end{array}$ & $\begin{array}{c}103 \\
25.89 * * *\end{array}$ & $\begin{array}{c}103 \\
54.45^{* * *} \\
0.412\end{array}$ & $\begin{array}{c}103 \\
35.29 * * *\end{array}$ & $\begin{array}{c}103 \\
47.93 * * * \\
0.348\end{array}$ \\
\hline $\begin{array}{c}\text { McFadden } \mathrm{R}^{2} \\
\text { Correct Predict \% }\end{array}$ & $\begin{array}{c}0.292 \\
86.41 \%\end{array}$ & $\begin{array}{c}0.291 \\
84.47 \%\end{array}$ & $\begin{array}{c}0.412 \\
81.55 \%\end{array}$ & $\begin{array}{c}0.273 \\
73.79 \%\end{array}$ & $\begin{array}{c}0.348 \\
77.67 \%\end{array}$ \\
\hline
\end{tabular}

Note: Asterisks indicate the confidence level of result: ${ }^{*} p \leq 0.10,{ }^{* *} p \leq 0.05,{ }^{* * *} p \leq 0.01$ 
Table 6. Probit model results from Opequon plus Abrams Creek watershed, only marginal effect coefficients with statistical confidence levels of $p \leq .10$ are reported in parentheses

\begin{tabular}{|c|c|c|c|c|c|}
\hline & \multicolumn{5}{|c|}{ Interest in Stream Improvement Project } \\
\hline & $\begin{array}{l}\text { Conservation } \\
\text { Easement }\end{array}$ & Fencing & $\begin{array}{l}\text { Stream bank } \\
\text { Restoration }\end{array}$ & Tree Planting & None \\
\hline $\begin{array}{c}\text { Stream Concern } \\
\text { Variables }\end{array}$ & $\begin{array}{l}\text { Bank erosion } \\
(-0.277)^{* * *}\end{array}$ & & & & \\
\hline $\begin{array}{c}\text { Respondent } \\
\text { Knowledge and } \\
\text { Demographics } \\
\text { Variables } \\
\end{array}$ & $\begin{array}{l}\text { Education }(0.150)^{* * *} \\
\text { Gender( }(0.336)^{* * *}\end{array}$ & & $\begin{array}{l}\text { Education } \\
(0.131)^{* * *}\end{array}$ & $\begin{array}{c}\text { Education } \\
(0.298)^{* * *} \\
\text { TMDL }(-0.368)^{* * *}\end{array}$ & $\begin{array}{c}\text { Age }(0.010)^{* *} \\
\text { Education }(0.295)^{* * *} \\
\text { Gender }(0.459)^{* * *} \\
\text { TMDL }(-0.279)^{*} \\
\end{array}$ \\
\hline $\begin{array}{c}\text { Agricultural Land } \\
\text { Owner Variable }\end{array}$ & $(0.563)^{* * *}$ & $\begin{array}{c}(0.814)^{* *} \\
*\end{array}$ & & $(0.668)^{* * *}$ & $(0.382)^{* * *}$ \\
\hline $\begin{array}{l}\text { Government Cost } \\
\text { Share Variable }\end{array}$ & $(0.141)^{*}$ & & $(0.199)^{* *}$ & & \\
\hline Model Summary & & & & & \\
\hline Number of obs. & 82 & 82 & 82 & 82 & 82 \\
\hline Chi-squared & $35.49 * * *$ & $45.39 * * *$ & 12.72 & $42.21^{* * *}$ & $37.70^{* * *}$ \\
\hline McFadden $\mathrm{R}^{2}$ & 0.380 & 0.582 & 0.140 & 0.419 & 0.341 \\
\hline Correct Predict \% & $86.59 \%$ & $91.46 \%$ & $74.39 \%$ & $84.15 \%$ & $76.83 \%$ \\
\hline
\end{tabular}

Note: Asterisks indicate the confidence level of result: ${ }^{*} \mathrm{p} \leq 0.10,{ }^{* *} \mathrm{p} \leq 0.05,{ }^{* * *} \mathrm{p} \leq 0.01$

Table 7. Comparison of respondent interest in stream improvement on own property versus the river in general, Cacapon River Watershed

\begin{tabular}{|c|c|c|}
\hline Stream Improvement Project & $\begin{array}{c}\text { Interest in Doing on Own } \\
\text { Property, N=77 (\%) }\end{array}$ & $\begin{array}{c}\text { Should be Done on the River in } \\
\text { General, N=78(\%) }\end{array}$ \\
\hline Conservation Easement & 9.1 & $37.2^{* * *}$ \\
\hline Enhanced Fish and Wildlife Habitat & 22.1 & $62.8^{* * *}$ \\
\hline Public Access for Recreation & 0.0 & $15.4^{* * *}$ \\
\hline Riverbed Restoration & 10.4 & $37.2^{* * *}$ \\
\hline Tree planting & 26.0 & $51.3^{* * *}$ \\
\hline None of the above & 7.8 & 6.4 \\
\hline
\end{tabular}

Note: Asterisks indicate the confidence level of statistical difference between percentages: ${ }^{* * *} \mathrm{p} \leq .01$ 


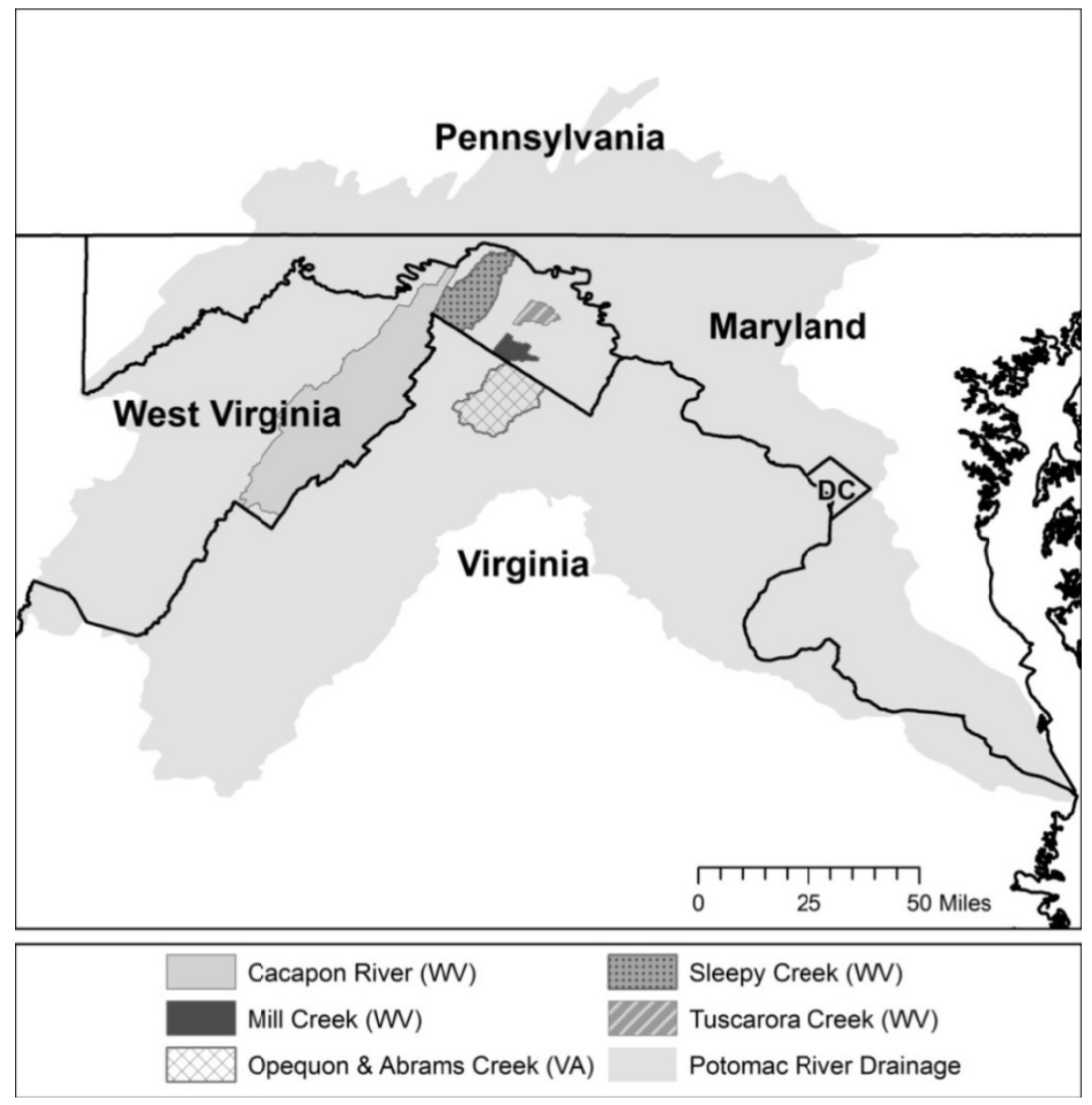

Figure 1. Location of study area watersheds in the Potomac River watershed

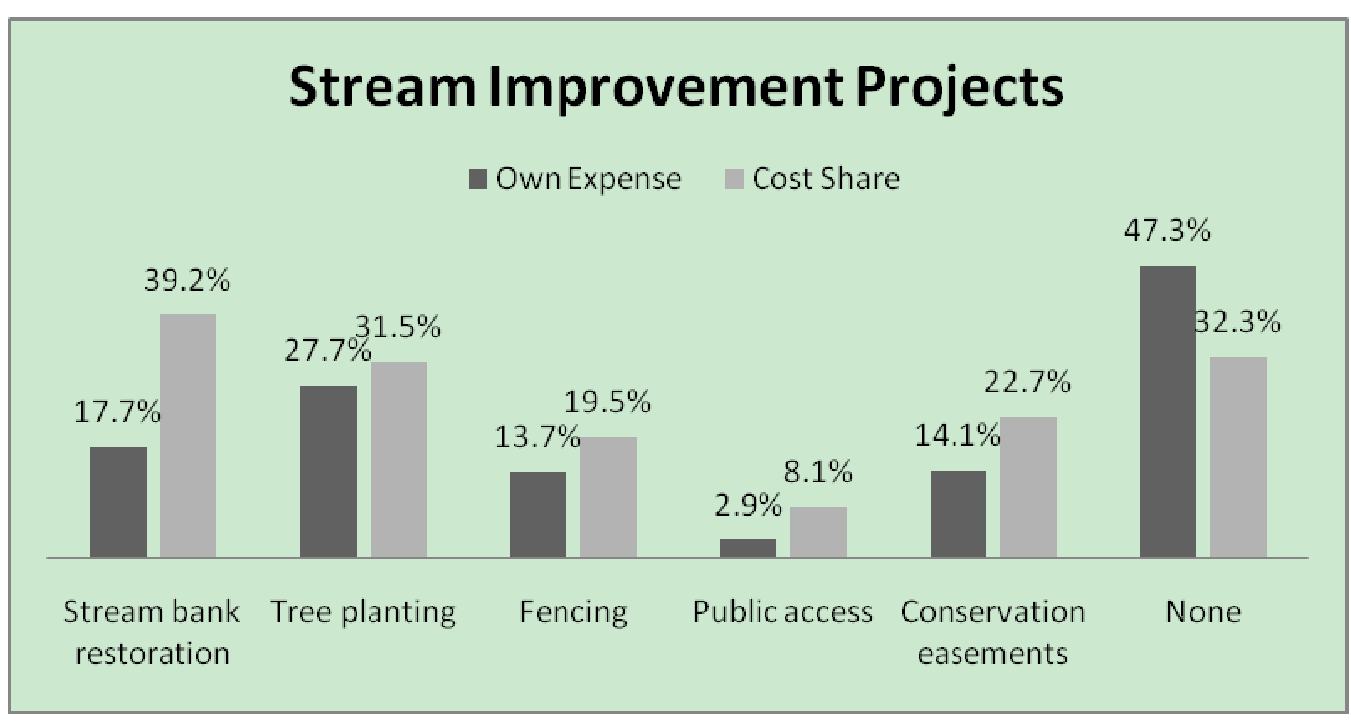

Figure 2. Riparian landowner interest in stream improvement projects with and without government cost share on Mill, Tuscarora, Opequon, and Abrams Creeks 